Institute for Research on Poverty

Discussion Paper no. 1160-98

\title{
Are Suburban Firms More Likely to Discriminate Against African Americans?
}

\author{
Steven Raphael \\ Department of Economics \\ University of California, San Diego \\ E-mail: sraphael@weber.ucsd.edu \\ Michael A. Stoll \\ Department of Policy Studies \\ School of Public Policy \\ University of California, Los Angeles \\ E-mail: mstoll@ucla.edu \\ Harry J. Holzer \\ Department of Economics \\ Michigan State University \\ E-mail: holzer@pilot.msu.edu
}

April 1998

The authors thank Cynthia Bansak, Graham Elliott, Clive Granger, Mark Machina, Jess Reaser, David Riker, and Julian Ware for helpful comments and suggestions.

IRP publications (discussion papers, special reports, and the newsletter Focus) are now available on the Internet. The IRP Web site can be accessed at the following address: http://www.ssc.wisc.edu/irp/ 


\begin{abstract}
This paper presents a test of the hypothesis that employers in suburban locations are more likely to discriminate against African Americans than are employers located in central cities. Using a difference-in-difference framework, we compare central-city/suburban differences in racial hiring outcomes for firms where a white person is in charge of hiring (white employers, for short) to similar geographic differences in outcomes for firms where a black person is in charge of hiring (black employers). We find that both suburban black and white employers hire fewer blacks than their centralcity counterparts. Moreover, the central-city/suburban hiring gap among black employers is as large as, or larger than, that of white employers. Suburban black employers, however, receive many more applications from blacks and hire more blacks than do white firms in either location.
\end{abstract}




\section{Are Suburban Firms More Likely to Discriminate Against African Americans?}

\section{INTRODUCTION}

Much recent research has been devoted to assessing the role of urban geography in explaining persistent racial differentials in labor market outcomes. In particular, considerable effort has been expended in evaluating the relative importance of the "spatial mismatch" hypothesis. Proponents of the mismatch hypothesis argue that racial housing segregation, in conjunction with the steady flow of employers from central-city to suburban locations, adversely affects the employment prospects of black and other minority workers. An important body of policy recommendations offered to aid in reducing the physical isolation of inner-city minorities stresses improving the accessibility of suburban employment centers through residential mobility programs and public transportation.

A key assumption of the mismatch hypothesis and the derived policy recommendations is that firms make location decisions independently of the racial residential distribution of workers. In other words, firms choose locations within metropolitan areas based on such factors as access to input and product markets, freeway accessibility, and land prices rather than the desire to maximize or minimize physical distance from workers of a particular racial or ethnic group. To the extent that this assumption holds and to the extent that physical distance impedes accessibility, the policy tools mentioned above would boost minority employment prospects.

On the other hand, if employers vary in their propensity to discriminate against minority workers and use physical distance from minority residential areas as a discrimination tool, the efficacy of policies to improve accessibility is called into question. When employers self-select across geographic regions according to their preferences for discrimination, connecting minority workers to suburban employment centers will not necessarily improve their employment prospects. This is due to the fact that minority 
workers are more likely to encounter discrimination in physically inaccessible suburban firms than in accessible central-city firms.

In this paper, we present a test of the hypothesis that employers geographically self-select into central-city and suburban locations according to their racial hiring preferences. We use a difference-indifference framework to isolate that portion of the central-city/suburban difference in racial hiring outcomes that can be attributed to spatial differences in racial employment discrimination. Using firmlevel data from the Multi-City Study of Urban Inequality for four large metropolitan areas, we compare central-city/suburban differences in racial hiring outcomes for firms where a white person is in charge of hiring (white employers, for short) to similar geographic differences in outcomes for firms where a black person is in charge of hiring (black employers). If we assume that firms where blacks are in charge of hiring do not discriminate against black workers and hence do not choose locations accordingly, geographic differences for these firms can be used to net out true distance effects and isolate the geographic difference in the propensity to discriminate among firms where whites are in charge of hiring.

We analyze geographic differences in three firm-level outcomes: the proportion of a firm's workforce that is black in jobs not requiring college degrees, the probability that the last worker hired is black, and the proportion of job applicants who are black. In addition, we construct ratios of the two employment outcomes to black application rates to analyze geographic differences in demand for black workers conditional on the supply of black workers to the firm. We use two alternative spatial characterizations of firm location: a simple central-city/suburban dichotomy and a more precise measure of relative spatial proximity to black residential areas. Furthermore, we control extensively for background firm characteristics, skill demands, and qualification requirements. The results indicate similar geographic differences for black and white employers-i.e., the lower tendency of suburban employers to hire black workers is at least as prevalent among black suburban employers (relative to 
black employers in the central city) as it is among whites. Race of the employer, however, does have large effects on employment outcomes within either location.

\section{ACCESSIBILITY AND THE EMPLOYMENT PROSPECTS OF BLACK WORKERS}

Underlying the spatial mismatch interpretation of racial differences in unemployment rates and wages is the notion that physical distance between the residences of minority workers and the location of employment opportunities impedes accessibility. Assuming that residential and firm locations are exogenously given, ${ }^{1}$ urban space limits job accessibility in two ways. First, commute costs reduce net wages and, thus, the relative attractiveness of distant employment opportunities. Barriers to reverse commuting that may render such costs prohibitive include low car-ownership rates among minority workers (Holzer, Ihlanfeldt, and Sjoquist 1994; Taylor and Ong 1995) and weak public transit links between suburban and central-city communities (Hughes and Sternberg 1992). Second, physical distance between minority workers and suburban employment centers may attenuate the flow of employment notices through informal information networks. To the extent that employers use such informal recruiting techniques as interviewing walk-ins, taking referrals from current employees, and posting help-wanted signs, the probability of securing employment in any given neighborhood will be higher for residents than for nonresidents.

One line of research within the spatial mismatch literature analyzes the effect of space on employment accessibility by estimating the relationship between distance from minority neighborhoods and minority employment shares. Kain (1968) presents evidence for the Chicago and Detroit metropolitan areas showing that the percentage of workers who are black in a given workplace area

\footnotetext{
${ }^{1}$ In an attempt to address the possible endogeneity of residential location, many mismatch studies focus on the employment outcomes of youths living at home, noting that such youths have little say in the location decision. The endogeneity of firm locations is essentially the subject of the current paper.
} 
declines with physical distance from the edge of major black neighborhoods. In a similar study using establishment-level data for Chicago and Los Angeles, Leonard (1987) finds that an establishment's black male share of blue collar employment declines with distance from black residential areas for both cities. In a more recent study, Holzer and Ihlanfeldt (1996) create a measure of a firm's proximity to blacks relative to proximity to whites and find that in addition to a strong negative distance effect, the percentage of blacks in a firm's noncollege workforce declines with the firm's distance from public transit stops. Similarly, in an analysis of Atlanta fast-food establishments, Ihlanfeldt and Young (1996) find that an establishment's proximity to Atlanta's commuter rail system and its distance from the central city both have strong significant effects on the racial composition of a firm's workforce.

An alternative methodological approach attempts to directly measure intrametropolitan spatial variation in labor demand and then to estimate the effect of these "accessibility indices" on either neighborhood-level or individual employment outcomes. For example, Ellwood (1986), Leonard (1985), and O’Regan and Quigley (1996) construct accessibility indices measuring intrametropolitan variation in proximity to employment levels and find small or negligible effects of accessibility on both tract-level youth employment rates (Ellwood 1986, Leonard 1985) and youth individual employment probabilities (O’Regan and Quigley 1996). Ihlanfeldt (1992) and Ihlanfeldt and Sjoquist (1990, 1991) use the variation in average commute times for low-wage workers across residential areas to measure accessibility and find strong effects of commute times on individual youth employment probabilities consistent with the mismatch hypothesis. Similarly, Raphael (1998a) constructs measures of spatial proximity to areas of high net employment growth and finds strong effects of spatial accessibility on neighborhood youth employment rates.

While a considerable body of evidence appears to indicate that space does matter, the existing body of empirical mismatch research rests on two strong assumptions: (1) that racial segregation in housing is involuntarily imposed on African Americans and (2) that the flow of jobs from central-city to 
suburban neighborhoods occurs for reasons that are independent of racial residential patterns. While substantial research indicates that racial housing segregation is to some degree involuntary, ${ }^{2}$ there is little evidence concerning the motivation behind firm relocations. On the one hand, traditional explanations of employment decentralization stress racially neutral interpretations such as the shift in transportation modes from rail to truck and the consequent premium placed on freeway accessibility, land-price differentials, changes in production technologies requiring increased horizontal space, proximity to the majority workforce, and proximity to spatial concentrations of consumer dollars (Kasarda 1985, 1989). To the extent that such explanations account for the rise of suburban employment centers, the effect of space on minority employment and earnings can be thought of as "real" in that policies designed to eliminate spatial barriers will improve minority employment prospects.

On the other hand, as noted by Fernandez (1997), firm relocations may be driven by a desire to avoid minority workers. Here, firms that discriminate for reasons of taste have several tools available to them to engage such tastes, such as flat-out refusing to interview or hire black workers, and a suburban location simply becomes an alternative option. In the extreme case where all discriminating firms choose suburban locations and all nondiscriminating firms choose central-city locations, one could argue that employment decentralization has no effect on minority employment prospects since suburban firms would not hire minority workers no matter where they were located. Stated another way, the effects of policies designed to facilitate reverse commuting or residential mobility would be minimal since the observed effect of space is "illusory" or driven by the selective out-migration of firms from central cities.

In addition, being located in the suburbs might causally reduce the hiring of blacks relative to being located in the central city. For instance, the preferences of white customers or employees might

\footnotetext{
${ }^{2}$ Yinger (1995) presents extensive evidence from the most recent national housing audit studies that documents considerable racial discrimination in both rental and sales housing markets. Massey and Denton (1993) present a detailed historical discussion of the evolution of racial segregation in U.S. metropolitan areas. In addition, Frey and Farley (1996) offer evidence that blacks are considerably more segregated than other racial and ethnic minorities.
} 
induce greater discrimination among suburban employers (Becker 1971). Furthermore, suburban employers might feel less subject to Equal Employment Opportunity regulation (Bloch, 1994) or to informal pressure from local residents to hire more blacks. Having less frequent contact with black employees might also tend to reinforce negative stereotypes of central-city blacks among suburban employers.

The conjecture that suburban employers are more discriminatory in their hiring practices than those located in the central city appears plausible, is indirectly supported by several empirical findings, and hence deserves attention. For example, in an analysis of the Washington, DC metropolitan area, Stoll (forthcoming) finds that the central-city/suburban employment rate differential is greater for white youth than for black and Hispanic youth. These results suggest that the effect of improved accessibility on the employment prospects of minority youth is partially offset by greater discrimination in suburban labor markets. Raphael (1998b) finds similar results from an analysis of the Oakland metropolitan area. In an analysis of four large metropolitan areas, Holzer (1996) finds that the ratio of black new hires to black application rates is lower in suburban firms than in central-city firms. This indicates a geographic difference in the rate at which blacks are hired, controlling for black labor supply to the firm. In addition, in an audit study of the DC area, where matched pairs of auditors who differ with respect to race apply for the same jobs, Bendick, Jackson, and Reinoso (1994) find considerable geographic differences in the net rate of discrimination experienced by the minority auditor. While there is little difference in the net rate of discrimination between firms located in DC proper and firms located in the Maryland suburbs, net discrimination rates are considerably higher for employers located in the Virginia suburbs than in either DC or Maryland.

The suspicion that employment decentralization is correlated with the racial hiring preferences of employers qualifies the implications of existing mismatch research. For example, the findings of Holzer and Ihlanfeldt (1996) and Ihlanfeldt and Young (1996) that a firm's distance from the black community 
and distance from transit stops negatively affect the black share of employment can be interpreted as firms explicitly choosing to locate away from black neighborhoods at locations inaccessible by public transit to avoid having to interview and hire black workers. Alternatively, the findings of Raphael (1998a) that differential proximity to employment growth explains a substantial portion of the blackwhite neighborhood employment rate differential can be alternatively interpreted as spatial residential concentrations of black youth reverse causing the outflow of firms. Below, we outline a simple test for gauging the extent to which racial discrimination is correlated with location.

\section{EMPIRICAL METHODOLOGY AND DATA DESCRIPTION}

Following the line of research initiated by Kain (1968), we analyze the relationship between establishment location and establishment-level racial employment outcomes. Specifically, let \%Black $\mathrm{ij}_{\mathrm{ij}}$ equal the percentage of a firm's workforce that is black at a firm where the person in charge of hiring is of race $i(\mathrm{i}=\mathrm{w}, \mathrm{b}$, for white and black) and located within area $j(\mathrm{j}=\mathrm{cc}, \mathrm{s}$, for central city and suburb) of the metropolitan area. Geographic differences in the propensity to hire blacks, overall and separately by the race of the individual in charge of hiring, are given by

$$
\begin{aligned}
& \Delta \% \text { Black }_{g}=\text { OBlack }_{., c c}-\% \text { Black }_{.,}, \\
& \Delta \% \text { Black }_{g_{w}}=\% \text { Black }_{w c c}-\% \text { Black }_{w s} \\
& \Delta \% \text { Black }_{g_{b}}=\% \text { Black }_{b c c}-\% \text { Black }_{b s} .
\end{aligned}
$$

Similarly, racial differences in the propensity to hire blacks, overall and separately by geographic area, are 


\section{8}

$$
\begin{gathered}
\Delta \% \text { Black }_{r}=\% \text { Black }_{w,}-\% \text { Black }_{b,} . \\
\Delta \% \text { Black }_{r_{c c}}=\% \text { Black }_{w c c}-\% \text { Black }_{b c c} \\
\Delta \% \text { Black }_{r_{s}}=\% \text { Black }_{w s}-\% \text { Black }_{b s} .
\end{gathered}
$$

If we assume that black employers do not discriminate against black workers and hence make location choices independently of the residential distributions of blacks, and also that blacks are residentially concentrated in the city, an estimate of the portion of the geographic differential in \%Black among white firms that is due to differences in the propensity to discriminate is

$$
\Delta \% \text { Black }=\Delta \% \text { Black }_{g_{w}}-\Delta \% \text { Black }_{g_{b}}=\Delta \% \text { Black }_{r_{c c}}-\Delta \% \text { Black }_{r_{s}}
$$

The difference-in-difference (DD) estimate in equation (3) implicitly assumes that no other systematic differences in variables exist across the four types of firms that affect the demand for black labor independently of an employer's racial hiring preferences. Geographic differences may exist, however, in the skill requirements of firms, industrial composition, or the possible discriminatory tastes of a firm's customer base. To control for possible differences in other important explanatory variables, alternative estimates of the various differentials are obtained by estimating the equation

$$
\% \text { Black }_{i}=\alpha_{0}+\alpha_{1} \text { Black }_{i}+\alpha_{2} \text { Suburb }_{i}+\alpha_{3} \text { Black }_{i} * \text { Suburb }_{i}+\beta X_{i}+\varepsilon_{i},
$$

where Black $_{\mathrm{i}}$ and $\mathrm{Suburb}_{\mathrm{i}}$ are dummy variables indicating that firm $i$ is a black or suburban firm, $\mathrm{X}_{\mathrm{i}}$ is a vector of explanatory variables, and $\varepsilon_{\mathrm{i}}$ is an error term. In equation (4), coefficient $\alpha_{1}$ represents the overall racial differential, coefficient $\alpha_{2}$ gives the geographic differential for white firms, the sum of the coefficients $\alpha_{2}$ and $\alpha_{3}$ gives the geographic differential for black firms, and coefficient $\alpha_{3}$ provides the DD estimate after controlling for variables in $\mathrm{X}_{\mathrm{i}}$. This coefficient is directly comparable to the discrimination differential, $\Delta \%$ Black, given by equation (3). Below, we present estimation results for specifications of equation (4) that include extensive controls for firm characteristics, variables indicating skill needs and qualification requirements, and a proxy for the extent of customer discrimination. 
The critical assumption identifying the tests in equations (3) and (4)-i.e, that location is exogenous for black employers-requires further discussion. Several arguments suggest that racial employment discrimination should be less prevalent (and therefore less of a factor in the location decision) at firms where blacks have authority over hiring decisions. To the extent that blacks are less likely to discriminate against blacks than are whites, there will be less discrimination among black employers due to a causal relationship between the race of the person in charge of hiring and employment outcomes. Alternatively, the race of the hiring agent may in itself be endogenous to hiring practices at the firm-i.e., unobservables causing blacks to be promoted to positions of authority may be correlated with those leading to high black hiring and employment rates. For our purposes, whether or not a causal relationship exists between the race of the hiring agent and employment outcomes is of secondary importance since we are primarily interested in identifying firms where racial hiring preferences play a minimal role in the location choice.

There are reasons to believe that black suburban employers are less likely to discriminate against black applicants than are white suburban employers, and perhaps no more likely than are black centralcity employers. Several studies indicate that minority suburban firms actively recruit minority workers. Bates $(1993,1994)$ provides evidence from a large 1987 survey of small businesses from 28 metropolitan areas showing that the black share of employment at black-owned firms is high for firms located in predominantly minority and nonminority areas. For the latter group of firms, average black employment shares exceed the black share of the resident population, a finding we are also able to reproduce in our data. In a descriptive case study of Detroit firms in the auto supply industry, Turner (1997) presents comparative results from interviews with several black entrepreneurs, some with businesses located in the suburbs and some with businesses located in the city. Turner finds that suburban black employers make considerable efforts to employ blacks. While neither of these studies presents clear and decisive 
evidence concerning the relative hiring preferences of suburban black employers versus central-city black employers, the results are instructive.

Nonetheless, several reasonable objections can be raised to our identifying assumption. First, suburban black firms may themselves self-select into suburban locations in order to avoid minority workers based on either personal animus or prior beliefs concerning the relative competence of workers by race. Alternatively, minority suburban employers may have more conservative views concerning the extent of racial discrimination in modern labor markets and, hence, may be relatively less proactive in seeking out and hiring minority employees. Moreover, since our data are based on interviews with the person in charge of hiring at the firm who may or may not be the owner, suburban blacks in positions that make hiring decisions may have less power and influence than comparable central-city blacks. Such geographic differences in internal power among black hiring agents may be further compounded by pressures in predominantly white suburban areas against engaging in hiring practices that are either racially neutral or that favor black applicants. The most obvious example of such pressures would be those exerted through customer discrimination (Holzer and Ihlanfeldt 1998). More generally, however, black suburban employers may simply be under greater social pressures to "act white."

With respect to the contention that suburban black employers may hold relatively more conservative views, a simple test of this argument would compare the beliefs of suburban and centralcity black employers. We have been unable to find any such comparisons, but it is possible to compare the beliefs of suburban black residents to central-city black residents using the National Opinion Research Center's General Social Survey (GSS). Such comparisons yield no evidence that blacks residing in the suburbs hold more conservative views than blacks residing in the central city. ${ }^{3}$ Hence, to

\footnotetext{
${ }^{3}$ Several questions asked of black respondents permit a geographic comparison of beliefs. In 1982, the survey asked black respondents whether they believed that "a black person who has the same education and qualifications can get as a good a job as a white person," and a similarly worded question concerned whether a black worker can make as much money. For black central-city residents of the 100 largest standard metropolitan statistical areas, 28 percent responded "almost never" to the good-job question while the comparable figure for
} 
the extent that the beliefs of suburban black residents extend to suburban black employers, the GSS results indirectly support our identifying assumption for the DD estimate.

The objections concerning the internal position within the firm of the person in charge of hiring and the existence of social pressures in the suburbs that do not exist in central cities require careful consideration. In a situation where a black hiring agent is not the firm's owner, the hiring decisions of the black employee will reflect the preferences of the institution in addition to the individual. If the owner of the firm is not black, hiring policies may favor minority workers to a lesser extent than in a comparable black-owned firm. In the empirical work below, we address this problem by controlling for the position within the firm of the person in charge of hiring and by allowing separate effects of position by race. To incorporate differential social pressures, we control for the racial composition of a firm's customer base to account for spatial differences in consumer discrimination. Concerning general pressures for conformity in suburban neighborhoods, however, no variables in the current data set can decisively control for such a possibility. Hence, in interpreting the results presented below, this caveat must be kept in mind.

We provide estimates of the racial and geographic differentials in equations (1) through (3) and various specifications of equation (4) for three firm-level outcomes: the proportion of a firm's noncollege workforce that is black, the probability that the last worker hired is black, and the percentage of a firm's applicant pool that is black. The first measure provides an overall description of the average hiring policies of the firm while the second measure provides a gauge of hiring decisions most likely to be made by the current person in charge of hiring. The percentage of applicants who are black provides

suburban blacks was 50 percent. Similarly, in response to the question concerning the ability to earn as much money, 30 percent of black central-city respondents answered "almost never" compared to 41 percent of suburban blacks. In a question administered in 1987, black respondents were asked to place themselves on a numeric scale according to their beliefs concerning the "best way for blacks to improve their position," with "civil rights groups" receiving a score of 1 and "become better trained and more qualified" receiving a score of 7 . Both suburban and central-city black residents had average responses of approximately 5.2. 
information on the potential differences between firms in the supply of black workers caused by either location or the geographical flow of information through informal networks to potential black employees.

In addition, we construct ratios of each employment outcome to application rates across firms, reflecting the demand for black applicants conditional on where they apply. The ratio of black new hires to black application rates indicates the rate at which firms hire blacks out of the available pool of black applicants. On the other hand, if one makes the strong assumption that firm hiring practices are in a steady state, the ratio of the black share of employment to black application rates reflects the firm's propensity to hire and retain black employees. From the regression equations for the dependent variables described above, we can also generate ratios of the predicted values of black employees to applicants. This provides a measure of the conditional demand for black applicants that controls for the other characteristics of jobs and firms. $^{4}$

The data used here come from the Multi-City Study of Urban Inequality (MCSUI). The employer survey was carried out between June 1992 and May 1994 in the Atlanta, Boston, Detroit, and Los Angeles metropolitan areas and was administered to over 3,000 firms. The sample of firms comes from two sources: a household survey conducted concurrently in the four metropolitan areas (providing approximately 30 percent of the firms) and a sample generated by Survey Sampling Incorporated (SSI). The SSI sample is a random-stratified sample where the initial lists are stratified by establishment size and firms are sampled according to the proportion of metropolitan area employment accounted for by their respective size categories. Hence, the SSI sample is representative of the set of firms faced by a job seeker in any of the four metropolitan areas. We use sample weights in all tabulations and model estimations to account for the nonrepresentative portion of the sample from the household surveys. The

\footnotetext{
${ }^{4}$ Note, to the extent that the supply of black workers to the firm is endogenous to the firm's racial hiring preferences, these ratios will be biased toward one.
} 
response rate for firms that passed the initial screening is 67 percent. Holzer (1996) provides detailed comparisons of response rates for the survey by industry, location, and establishment size and finds no substantial differences in response rates across firms. In addition, Holzer (1996) provides evidence that the distribution of firms in the MCSUI sample within areas across industry and firm size are comparable to those found in County Business Patterns.

Telephone surveys were conducted with the individual in charge of hiring, and extensive information was recorded concerning background characteristics of the firm, hiring and screening behavior, skill demands and requirements, and several race-based employment outcomes. We restrict the sample to records with complete information and to records where either a black person or a white person was in charge of hiring. We impose the second restriction to present a clean test for a geographic difference in the propensity to discriminate among white employers (the majority of firms). Imposing the restriction does not noticeably alter the results presented below.

\section{RESULTS}

In this section we first present estimates of the differentials in equations (1) through (4) for the three outcomes and two ratios discussed above, using a simple central-city/suburban dichotomy to characterize the proximity of firms to black residential areas. We define central-city firms as those with mailing addresses in the primary central cities of the four metropolitan statistical areas (MSAs). ${ }^{5} \mathrm{Next}$, we use a more precise measure of firm location based on the relative proximity of the census tract in

\footnotetext{
${ }^{5}$ Our definition of central city closely parallels the municipal boundaries used by the Bureau of the Census for Atlanta, Boston, and Detroit. For Los Angeles, however, our definition of central city places the San Fernando Valley in the suburbs rather than the central city and places the predominantly minority areas in East Los Angeles in the city rather than in the suburbs. All of the results presented below were also estimated using (1) the municipal boundaries for all cities and (2) our definition of central city for Los Angeles and Detroit and municipal boundaries for Atlanta and Boston. The results using these alternative geographic definitions are qualitatively similar to what we present below and are available upon request.
} 
which the firm is located to black and white workers. This second specification provides a useful robustness check to the simple two-by-two comparisons implied by equations (1) through (4).

\section{A. Using the Central-City/Suburban Dichotomy to Characterize Firm Location}

Table 1 presents several sets of calculations for the three establishment-level outcomes. First, the table presents mean values of the outcomes for all firms, by location (i.e., central city or suburb), by race of the person in charge of hiring, and by location interacted with the race of the hiring agent. In addition, the table gives interlocational differences within firm racial groups, interracial differences within location, and DD calculations. The figures in Table 1 and all of the models estimated below use the sample of firms pooled across the four metropolitan areas. The MSA-specific tabulations presented in Appendix Tables A1 through A3 are comparable to those in Table 1. For the most part, the patterns within individual MSAs are quite similar to those for the pooled sample.

Before discussing the DD estimates, a brief discussion of the overall mean differences by location and race-i.e., $\Delta \%$ Black $_{\mathrm{g}}$ and $\Delta \%$ Black $_{\mathrm{r}}$ - is necessary. For all three outcomes, firms where blacks are in charge of hiring have considerably higher mean values than firms where whites are in charge of hiring. These differences by race are highly significant for the sample as a whole and within each location. Hence, regardless of location, race is not a neutral factor in the hiring and application outcomes observed in the data.

The interracial suburban differences are particularly important to the analysis here. Confirming the findings of Bates $(1993,1994)$, black firms in suburban locations employ and accept applications from blacks at a rate considerably higher than the black share of the resident population. ${ }^{6}$ While the

\footnotetext{
${ }^{6}$ The distribution of black shares of employment presented by Bates $(1993,1994)$ indicates higher proportions black than the numbers presented in Table 1. The divergence between our result and those of Bates is most likely attributable to the fact that Bates focuses on black-owned firms while in our sample any firm with a black person in charge of hiring is designated a black firm. In addition, Bates's work focuses on the small-business sector while the MCSUI sample includes a distribution of firms across size categories that is similar to the comparable distribution of employment shares.
} 
TABLE 1

Means and DD Calculations for Various Firm-Level Employment Outcomes by Location and the Race of the Person in Charge of Hiring

\begin{tabular}{|c|c|c|c|c|}
\hline & All Firms & Central City & Suburb & Difference \\
\hline \multicolumn{5}{|c|}{ Proportion of Noncollege Employees Who Are Black } \\
\hline All firms & $.180 \quad(.005)$ & $.331 \quad(.013)$ & $.133(.005)$ & $.198(.011)$ \\
\hline White person in charge of hiring & $.159(.005)$ & $.282 \quad(.013)$ & $.125(.005)$ & $.157(.011)$ \\
\hline Black person in charge of hiring & $.516 \quad(.024)$ & $.676 \quad(.027)$ & $.353(.033)$ & $.323(.042)$ \\
\hline Difference & $-.357 \quad(.021)$ & $-.394(.035)$ & $-.227(.025)$ & $-.166(.040)$ \\
\hline
\end{tabular}

Last Noncollege Employee Hired Is Black

$\begin{array}{lrlrlrlrl}\text { All firms } & .203 & (.008) & .355 & (.009) & .153 & (.009) & .202 & (.018) \\ \text { White person in charge of hiring } & .183 & (.008) & .309 & (.020) & .145 & (.009) & .164 & (.019) \\ \text { Black person in charge of hiring } & .489 & (.035) & .661 & (.046) & .316 & (.049) & .344 & (.067) \\ \text { Difference } & -.305 & (.033) & -.351 & (.053) & -.171 & (.042) & -.180 & (.065)\end{array}$

Proportion of Applicants Who Are Black

\begin{tabular}{lllllllll} 
All firms & .306 & $(.009)$ & .482 & $(.019)$ & .249 & $(.009)$ & .233 & $(.019)$ \\
White person in charge of hiring & .282 & $(.009)$ & .439 & $(.020)$ & .236 & $(.009)$ & .203 & $(.019)$ \\
Black person in charge of hiring & .624 & $(.034)$ & .750 & $(.045)$ & .505 & $(.049)$ & .245 & $(.066)$ \\
Difference & -.341 & $(.032)$ & -.311 & $(.054)$ & -.269 & $(.042)$ & -.042 & $(.064)$ \\
\hline
\end{tabular}

Notes: Standard errors are in parentheses. All figures are weighted. 
average percentage of blacks in the census tract of the average black suburban employer in our sample is 5.3 percent, 35 percent of the noncollege employees at these firms are black, 31 percent of the most recent hires at these firms are black workers, and 50 percent of those in the applicant pool are black job seekers. In addition, for all three outcomes, black suburban employers have higher mean values than white central-city firms. Hence, these basic calculations provide at least some support for our key identifying assumption. Furthermore, the relatively high percentage of blacks applying to black suburban firms, and the relatively low percentage applying to white central-city firms, suggests that physical distance per se and related factors (such as transportation) may matter much less in determining where black workers apply for jobs than information flows or the perceptions of fair treatment.

Concerning the overall central-city/suburban differences, these are sizable and significant for all three outcomes, though generally smaller than the overall differences by race. Looking within employer racial groups, the central-city/suburban differences for black firms are actually greater than those for white firms for all three outcomes, yielding negative DD estimates corresponding to equation (3). All of the locational differences for black and white firms are significant at the 1 percent level. The largest disparities between the black and white geographic differences (and the ones yielding significant and negative DD estimates) occur for the proportion of noncollege employees who are black and for the lasthire outcomes. Hence, subject to the qualifications concerning the identifying assumption, the results from the DD calculations in Table 1 suggest that white suburban firms are no more likely to discriminate than are white central-city firms.

When computed as a percentage of the central-city base, the locational percentage changes for white and black employers are nearly identical for the two hiring outcomes and slightly larger for white employers for the proportion of applicants who are black. For the proportion of noncollege employees who are black and the probability that the most recent hire is black, both suburban black and white employers have mean values equal to approximately half that of their central-city counterparts. For the 
proportion-of-applicants measure, black suburban employers have mean application rates that are approximately 30 percent lower than those of central-city black employers, while the comparable figure for white suburban firms is 46 percent.

Table 2 uses the mean values in the first three columns of Table 1 to calculate ratios of each employment outcome to the mean black application rates. The first panel presents the ratio of the black share of noncollege employment to the black application rate while the second panel gives the ratio of the proportion of recent hires who are black to black application rates. The differences and the DD figures are actual differences in the ratios presented in Table 2 rather than ratios of the corresponding figures in Table 1. These ratios can be interpreted as the relative demand for black workers at the firm, conditional on the supply and quality of black applicants.

Similar to the findings of Holzer (1996), the two ratios are lower in the suburbs than in the central city, indicating a relatively lower propensity among suburban firms to hire blacks out of the pool of black workers who seek employment in suburban firms. In addition, these ratios are higher at firms where blacks are in charge of hiring. Within firms grouped by the race of the hiring agent, however, we find central-city/suburban differences among black employers that are either equivalent to, or larger than, those observed among white employers. Racial differences in the ratios are considerably larger in the central city than in the suburbs. Again, the negative (and sometimes significant) DD estimates do not suggest that white employers in the suburbs discriminate more than those in the central city.

While the patterns observed in Table 2 conform to the results in Table 1, the ratios do show that black suburban employers are less likely to employ black applicants conditional on supply than are black central-city employers. This pattern is somewhat counterintuitive. If anything, relative skills among black suburban applicants are likely to be higher than among black central-city applicants, given that educational attainment is positively correlated with suburban residence and commute distances among blacks (Holzer 1996). Perhaps the relatively low ratios observed for black (as well as white) suburban 
TABLE 2

Ratios of Black Hiring Outcomes to Black Application Rates

\begin{tabular}{|c|c|c|c|c|}
\hline & All Firms & Central City & Suburb & Difference \\
\hline \multicolumn{5}{|c|}{$\begin{array}{l}\text { Proportion of Noncollege Employees Who Are Black } \\
\text { Divided by the Proportion of Applicants Who Are Black }\end{array}$} \\
\hline All firms & $.622 \quad(.016)$ & $.715 \quad(.024)$ & $.565 \quad(.020)$ & $.150 \quad(.031)$ \\
\hline White person in charge of hiring & $.587 \quad(.017)$ & $.662(.028)$ & $.547 \quad(.020)$ & $.115(.035)$ \\
\hline Black person in charge of hiring & $.837 \quad(.036)$ & $.904 \quad(.041)$ & $.739 \quad(.064)$ & $.166(.076)$ \\
\hline Difference & $-.250 \quad(.040)$ & $-.242 \quad(.050)$ & $-.191 \quad(.067)$ & $-.051 \quad(.084)$ \\
\hline
\end{tabular}

Proportion of Recent Hires Who Are Black Divided

by the Proportion of Applicants Who Are Black

\begin{tabular}{lllllllll} 
All firms & .704 & $(.028)$ & .770 & $(.038)$ & .661 & $(.039)$ & .109 & $(.054)$ \\
White person in charge of hiring & .684 & $(.032)$ & .735 & $(.045)$ & .655 & $(.043)$ & .080 & $(.062)$ \\
Black person in charge of hiring & .822 & $(.047)$ & .900 & $(.060)$ & .719 & $(.076)$ & .181 & $(.096)$ \\
Difference & -.138 & $(.057)$ & -.165 & $(.075)$ & -.064 & $(.087)$ & -.101 & $(.114)$ \\
\hline
\end{tabular}

Notes: Standard errors are in parentheses. Ratios are computed from averages of the numerator and denominator using a sample that is restricted to observations containing information for both variables. Due to this additional restriction, the ratios presented here differ slightly from those implied by the mean values given in Table 1. 
employers are due to concerns about potential problems of absenteeism or turnover related to transportation difficulties. Alternatively, there may be discriminatory differences in preferences between suburban and central-city employers of either race, for reasons noted above. The latter would violate the identifying assumption-i.e., comparable preferences between suburban and central-city black employers-behind our DD estimates, although we cannot be sure with these data that this interpretation is correct. At a minimum, the results from Tables 1 and 2 imply that both race and location effects limit the employment of black applicants at suburban firms.

Thus far we have not taken into account possible differences by region and firm racial group in characteristics that may affect the demand for black labor. Appendix Table A4 provides average values for a host of firm characteristics by the race of the person in charge of hiring and by geographic location. The table lists several groups of variables: a set of basic firm descriptive statistics (size, industry, and location), indicators of the respondent's position within the firm, a set of variables indicating the daily job tasks and job qualification demanded of the last hire, and indicators of whether the firm uses affirmative action in hiring. The table also presents information on the proportion of the firm's customers who are black and the relative distance of the firm from the black community. ${ }^{7}$ Some notable differences occur in the mean values of firm background characteristics both interracially and, within firm racial group, across locations. For example, black firms are somewhat larger on average than white firms, have a higher proportion of their workforce unionized, report that a higher proportion of their customers are black, and are more likely than white firms to use affirmative action in hiring and recruiting. Among black firms, respondents in suburban firms are less likely to be owners and more likely to be managers or supervisors than black city-firm respondents. Given the possible importance of these variables in

\footnotetext{
${ }^{7}$ The relative distance variable will be discussed in detail below.
} 
determining a firm's demand for black labor, the simple discrimination estimates presented in Tables 1 and 2 may suffer omitted-variables bias.

To account for possible bias, we estimate equation (4) incorporating these firm characteristics and skill needs variables. Table 3 presents estimation results for the probability that the last worker hired is black and the black share of the applicant pool using four specifications of equation (4). The first specification controls for the firm characteristics, daily job tasks, job qualifications, and affirmative action variables listed in Appendix Table A4. Next, the proportion of customers who are black is added. The third specification adds three dummy variables indicating position within the firm ("other" is the omitted category), while the fourth specification adds interactions between these dummy variables and the dummy indicating a black respondent. Recall from equation (4) that the DD coefficient comparable to the calculation in Table 1 is given by the coefficient on the interaction between the black respondent and suburban location dummies. All models are estimated using simple ordinary least squares regressions. ${ }^{8}$ We do not include corresponding model estimations for the black share of employment because the skill and qualification demands variables correspond to the last job filled and the recent batch of applicants and hence cannot be used to analyze black employment shares. ${ }^{9}$

Starting with the probability that the last worker hired is black, all of the DD coefficients are either negative or near zero. For the first three specifications in columns (1) through (3), the DD estimates are significant at the 5 percent level. The substantial interracial and locational probability differentials observed in Table 1 remain and are significant in all specifications, though controlling for

${ }^{8}$ The models for the probability that the last noncollege employee hired was black were also estimated using probits rather than linear probability models. This does not affect the results. In addition, the black share of applicants equations were estimated using tobit models due to the large number of zeros among white firms. This also does not affect the main results of the paper.

${ }^{9}$ We did estimate equations with the black share of noncollege employment as the dependent variable corresponding to the four specifications but withholding the skill and qualification demand variables. For all four specifications, the point estimate of the DD calculation was near zero and statistically insignificant. 
TABLE 3

Linear Regression Estimates of the Differential Effects of Space on Firm-Level Emplovment Outcomes

\begin{tabular}{|c|c|c|c|c|c|c|c|c|}
\hline \multirow[b]{2}{*}{ Variables } & \multicolumn{4}{|c|}{ Last Noncollege Employee Hired Is Black } & \multicolumn{4}{|c|}{ Proportion of Applicants Who Are Black } \\
\hline & $(1)$ & $(2)$ & (3) & $(4)$ & $(5)$ & (6) & $(7)$ & $(8)$ \\
\hline Suburbs & $\begin{array}{l}-.133 \\
(.019)\end{array}$ & $\begin{array}{l}-.086 \\
(.023)\end{array}$ & $\begin{array}{l}-.086 \\
(.022)\end{array}$ & $\begin{array}{l}-.084 \\
(.023)\end{array}$ & $\begin{array}{l}-.151 \\
(.020)\end{array}$ & $\begin{array}{l}-.106 \\
(.019)\end{array}$ & $\begin{array}{l}-.103 \\
(.019)\end{array}$ & $\begin{array}{l}-.102 \\
(.019)\end{array}$ \\
\hline Black respondent & $\begin{array}{l}.296 \\
(.046)\end{array}$ & $\begin{array}{c}.218 \\
(.050)\end{array}$ & $\begin{array}{c}.217 \\
(.051)\end{array}$ & $\begin{array}{c}.519 \\
(.104)\end{array}$ & $\begin{array}{c}.273 \\
(.045)\end{array}$ & $\begin{array}{l}.156 \\
(.042)\end{array}$ & $\begin{array}{l}.168 \\
(.043)\end{array}$ & $\begin{array}{l}.278 \\
(.085)\end{array}$ \\
\hline Suburbs*black respondent & $\begin{array}{l}-.159 \\
(.064)\end{array}$ & $\begin{array}{l}-.115 \\
(.068)\end{array}$ & $\begin{array}{l}-.113 \\
(.069)\end{array}$ & $\begin{array}{l}-.045 \\
(.071)\end{array}$ & $\begin{array}{l}-.034 \\
(.062)\end{array}$ & $\begin{array}{c}.016 \\
(.057)\end{array}$ & $\begin{array}{c}.001 \\
(.057)\end{array}$ & $\begin{array}{c}.057 \\
(.060)\end{array}$ \\
\hline Proportion of customers black & - & $\begin{array}{c}.608 \\
(.047)\end{array}$ & $\begin{array}{l}.616 \\
(.048)\end{array}$ & $\begin{array}{c}.611 \\
(.048)\end{array}$ & - & $\begin{array}{c}.756 \\
(.039)\end{array}$ & $\begin{array}{l}.749 \\
(.039)\end{array}$ & $\begin{array}{c}.749 \\
(.039)\end{array}$ \\
\hline Owner & - & - & $\begin{array}{c}.074 \\
(.036)\end{array}$ & $\begin{array}{c}.094 \\
(.037)\end{array}$ & - & - & $\begin{array}{l}.034 \\
(.030)\end{array}$ & $\begin{array}{c}.034 \\
(.031)\end{array}$ \\
\hline Manager/supervisor & - & - & $\begin{array}{c}.035 \\
(.031)\end{array}$ & $\begin{array}{c}.065 \\
(.032)\end{array}$ & - & - & $\begin{array}{c}.059 \\
(.026)\end{array}$ & $\begin{array}{c}.073 \\
(.027)\end{array}$ \\
\hline Personnel dept. official & - & - & $\begin{array}{c}.036 \\
(.035)\end{array}$ & $\begin{array}{c}.067 \\
(.036)\end{array}$ & - & - & $\begin{array}{c}.052 \\
(.029)\end{array}$ & $\begin{array}{c}.069 \\
(.031)\end{array}$ \\
\hline Owner*black respondent & - & - & - & $\begin{array}{l}-.244 \\
(.138)\end{array}$ & - & - & - & $\begin{array}{c}.033 \\
(.109)\end{array}$ \\
\hline Manager/supervisor*black respondent & - & - & - & $\begin{array}{l}-.427 \\
(.118)\end{array}$ & - & - & - & $\begin{array}{l}-.210 \\
(.097)\end{array}$ \\
\hline Pers. dept. official*black respondent & - & - & - & $\begin{array}{l}-.374 \\
(.118)\end{array}$ & - & - & - & $\begin{array}{l}-.179 \\
(.097)\end{array}$ \\
\hline $\mathrm{R}^{2}$ & .171 & .260 & .262 & .269 & .261 & .441 & .443 & .448 \\
\hline $\mathrm{N}$ & 2,264 & 1,598 & 1,598 & 1,598 & 1,579 & 1,341 & 1,341 & 1,341 \\
\hline
\end{tabular}

Notes: Standard errors are in parentheses. All regressions include a constant term and all of the firm characteristics and indicators of skill needs and job requirements listed in Appendix Table 4A (except the relative distance measure). 
all explanatory variables in Appendix Table A4 reduces the overall racial and locational differentials by approximately one-third. ${ }^{10}$ As for the proportion of applicants who are black, the coefficients on the suburb*black respondent interaction terms are all insignificant, and the coefficient is negative for the first specification in column (5). Hence, these results are largely consistent with the various calculations based on the summary statistics in Table $1 .{ }^{11}$

Concerning the other coefficient estimates reported in Table 3, similar to the findings of Holzer and Ihlanfeldt $(1996,1998)$, the proportion of customers who are black has strong and highly significant effects for outcomes and in all specifications. Concerning the respondent's position within the firm, there is an interesting pattern in the specification that interacts the race of the respondent with the position within the firm dummies. For black firms, we observe an ordering of effects on the two dependent variables that may roughly correspond to conjectures concerning the respondent's influence within the firm. For example, for both outcomes black owners have stronger positive effects on the dependent variables than either black managers/supervisors or black personnel department officials. For white firms we do not observe any consistent patterns in these specifications. In addition, in the specifications that exclude the interactions, the ranking of the effects according to internal position differs for the two outcomes.

\footnotetext{
${ }^{10}$ In addition to a greater propensity to discriminate in the suburbs, the overall geographic differential in the hiring and application outcomes may be driven in part by the different racial compositions of suburban and centralcity employers. In other words, in addition to being more likely to encounter discrimination at suburban firms among white employers, black job seekers are also less likely to encounter a black employer in the suburbs given the concentration of black employers in the central city. To gauge the extent to which this compositional effect explains the overall geographic differences observed in the data, we estimated models corresponding to those in Table 3 where we first estimate each regression omitting and then including the respondent's race. Such an exercise indicates that approximately 10 to 20 percent of the overall geographic differences in the two outcomes can be explained by the differential racial compositions of central-city and suburban employers.

${ }^{11} \mathrm{We}$ also estimated equations including triple interactions between position within the firm, location, and respondent's race. Such a specification permits black employers to behave differently by position and location. All DD calculations from these models remained insignificant, yet with considerably inflated standard errors.
} 
The results from Table 3 can be used to compute hiring-to-application ratios that hold constant the control variables in each regression. Table 4 presents these computed ratios by respondent's race, firm location, and the interaction between race and firm location as well as accompanying differences in the ratios and DD calculations. The table presents four sets of ratios corresponding to the four specifications from Table 3. Similar to the unadjusted ratios presented in the lower panel of Table 2, the ratio of black new hires to application rates is lower overall in the suburbs than in the central city and higher among black employers than among white employers. Controlling for the variables in Appendix Table A4, however, slightly narrows the overall locational difference for specifications (1) through (3). The geographic differences within firm racial groups observed in the unadjusted figures are also present in the ratios after controlling for firm characteristics, with the locational differences widening slightly for black firms and narrowing slightly for white firms. In all specifications, the locational difference for black firms exceeds considerably that for white firms and, consequently, all of the DD calculations are large and negative. Hence, controlling extensively for firm characteristics, skill needs and qualification demands, customer preferences, and the internal power of the hiring agent does not qualitatively alter the findings from the unadjusted results presented in Tables 1 and 2.

\section{B. An Alternative Characterization of Firm Proximity to Black Workers}

Employing a geographic coding scheme that classifies firm location as either suburban or central-city implicitly assumes that within region black and white employers are of equal distance, on average, from potential black employees. Given the existence of racial segregation within suburban communities and the possibility that black suburbanization simply reflects the extension of existing black neighborhoods across central-city boundaries, this spatial assumption is overly restrictive and may bias the results of the exercises presented in the previous section. For example, if black suburban employers locate at the peripheries of large black residential areas just over the city limit while white suburban 


\section{TABLE 4}

Ratios of the Proportion of Recent Hires Who Are Black to the Proportion of Applicants Who Are Black, Holding Constant Firm Characteristics, Skill Demand and Qualifications, Racial Composition of Customers, and Respondent's Position within the Firm

\begin{tabular}{|c|c|c|c|c|c|c|c|c|}
\hline & \multicolumn{2}{|c|}{ All Firms } & \multicolumn{2}{|c|}{ Central City } & \multicolumn{2}{|c|}{ Suburb } & \multicolumn{2}{|c|}{ Difference } \\
\hline \multicolumn{9}{|c|}{ Specification (1) } \\
\hline All firms & .704 & $(.029)$ & .750 & $(.020)$ & .678 & $(.034)$ & .072 & $(.039)$ \\
\hline White person in charge of hiring & .689 & $(.031)$ & .716 & $(.022)$ & 677 & $(.035)$ & .038 & $(.041)$ \\
\hline Black person in charge of hiring & .796 & $(.016)$ & .881 & $(.014)$ & 691 & $(.018)$ & .190 & $(.023)$ \\
\hline Difference & -.107 & $(.035)$ & -.165 & $(.026)$ & -.013 & $(.040)$ & -.152 & $(.047)$ \\
\hline \multicolumn{9}{|c|}{ Specification (2) } \\
\hline All firms & .686 & $(.030)$ & .743 & $(.023)$ & 658 & $(.033)$ & .085 & $(.041)$ \\
\hline White person in charge of hiring & .670 & $(.032)$ & .701 & $(.025)$ & .656 & $(.034)$ & .046 & $(.042)$ \\
\hline Black person in charge of hiring & .804 & $(.020)$ & .913 & $(.018)$ & .681 & $(.021)$ & .233 & $(.028)$ \\
\hline Difference & -.135 & $(.037)$ & -.212 & $(.031)$ & -.025 & $(.040)$ & -.187 & $(.050)$ \\
\hline \multicolumn{9}{|c|}{ Specification (3) } \\
\hline All firms & .686 & $(.030)$ & .743 & $(.023)$ & .658 & $(.033)$ & .085 & $(.041)$ \\
\hline White person in charge of hiring & .670 & $(.032)$ & .704 & $(.025)$ & .656 & $(.034)$ & .049 & $(.042)$ \\
\hline Black person in charge of hiring & .799 & $(.019)$ & .897 & $(.018)$ & .685 & $(.021)$ & .212 & $(.028)$ \\
\hline Difference & -.129 & $(.037)$ & -.193 & $(.031)$ & -.030 & $(.040)$ & -.163 & $(.050)$ \\
\hline \multicolumn{9}{|c|}{ Specification (4) } \\
\hline All firms & .686 & $(.030)$ & .767 & $(.023)$ & .645 & $(.033)$ & .122 & $(.041)$ \\
\hline White person in charge of hiring & .671 & $(.032)$ & .704 & $(.025)$ & .657 & $(.034)$ & .047 & $(.042)$ \\
\hline Black person in charge of hiring & .795 & $(.020)$ & .887 & $(.019)$ & .701 & $(.020)$ & .186 & $(.028)$ \\
\hline Difference & -.125 & $(.037)$ & -.183 & $(.031)$ & -.044 & $(.040)$ & -.139 & $(.050)$ \\
\hline
\end{tabular}

Notes: Standard errors are in parentheses. The ratios are calculated from model results corresponding to the specifications in Table 3 where the sample is constrained to observations with information for both dependent variables needed to construct the ratios. 
firms locate on the peripheries of the suburban ring, the dichotomous location scheme used above would effectively overstate for black suburban firms and understate for white suburban firms the distance to the residences of black workers. Such location patterns would impart an upward bias to the discrimination estimates presented in the previous section.

To account for this potential source of bias, here we abandon the simple central-city/suburban dichotomy and employ a continuous measure of relative proximity following Holzer and Ihlanfeldt (1996). Table 5 presents estimation results comparable to the models presented in Table 3 where a variable measuring the firm's relative distance to blacks in the metropolitan area is substituted for the suburban dummy variable. The relative distance variable is computed as follows. For each firm, a weighted average of the distance in miles between the firm's census tract and all other census tracts in the metropolitan area is computed using the tract counts of black residents as weights. This conceptually provides the average distance between the firm and black residents in the metropolitan area. Next, a similar distance measure is calculated for proximity to whites. The relative distance measure used in the models is the distance to blacks divided by the distance to whites. In addition, following Holzer and Ihlanfeldt (1996) we include four dummy variables indicating the firm's proximity to the nearest public transit stop. Table 5 suppresses the output for the position within the firm dummies since the results do not differ from those of Table 3.

For the recent-hire outcome the relative distance variable has a strong negative and significant effect in all specifications. Similar to the findings of Holzer and Ihlanfeldt (1996), we also observe that proximity to public transit exerts significant and substantial effects on the probability of a recent black hire. ${ }^{12}$ Concerning the interaction term, in all four specifications the point estimates are negative with a significant negative effect in specification (1). Hence, these results indicate that for black employers the

\footnotetext{
${ }^{12}$ Notably, the coefficients on the transit dummies decline uniformly in distance for all four specifications.
} 
TABLE 5

Linear Regression Estimates of the Differential Effects of the Relative Distance to the Black Population on Firm-Level Employment Outcomes

\begin{tabular}{|c|c|c|c|c|c|c|c|c|}
\hline \multirow[b]{2}{*}{$\underline{\text { Variables }}$} & \multicolumn{4}{|c|}{ Last Noncollege Employee Hired Is Black } & \multicolumn{4}{|c|}{ Proportion of Applicants Who Are Black } \\
\hline & $(1)$ & $(2)$ & $(3)$ & $(4)$ & $(5)$ & $(6)$ & $(7)$ & (8) \\
\hline Black respondent & $\begin{array}{l}.603 \\
(.129)\end{array}$ & $\begin{array}{l}.296 \\
(.139)\end{array}$ & $\begin{array}{l}.295 \\
(.140)\end{array}$ & $\begin{array}{l}.578 \\
(.164)\end{array}$ & $\begin{array}{l}.318 \\
(.122)\end{array}$ & $\begin{array}{c}.074 \\
(.116)\end{array}$ & $\begin{array}{l}.089 \\
(.117)\end{array}$ & $\begin{array}{l}.174 \\
(.137)\end{array}$ \\
\hline Relative distance & $\begin{array}{l}-.307 \\
(.049)\end{array}$ & $\begin{array}{l}-.224 \\
(.057)\end{array}$ & $\begin{array}{l}-.219 \\
(.057)\end{array}$ & $\begin{array}{l}-.217 \\
(.057)\end{array}$ & $\begin{array}{l}-.456 \\
(.048)\end{array}$ & $\begin{array}{l}-.271 \\
(.047)\end{array}$ & $\begin{array}{l}-.265 \\
(.048)\end{array}$ & $\begin{array}{l}-.260 \\
(.048)\end{array}$ \\
\hline Black respondent*relative distance & $\begin{array}{l}-.588 \\
(.186)\end{array}$ & $\begin{array}{l}-.181 \\
(.201)\end{array}$ & $\begin{array}{l}-.180 \\
(.201)\end{array}$ & $\begin{array}{l}-.097 \\
(.203)\end{array}$ & $\begin{array}{l}-.138 \\
(.177)\end{array}$ & $\begin{array}{l}.128 \\
(.171)\end{array}$ & $\begin{array}{l}.107 \\
(.171)\end{array}$ & $\begin{array}{l}.186 \\
(.172)\end{array}$ \\
\hline $\begin{array}{l}\text { Distance to transit } \\
\quad 0 \text { miles }\end{array}$ & $\begin{array}{c}.086 \\
(.022)\end{array}$ & $\begin{array}{c}.066 \\
(.025)\end{array}$ & $\begin{array}{c}.066 \\
(.024)\end{array}$ & $\begin{array}{c}.065 \\
(.024)\end{array}$ & $\begin{array}{l}.119 \\
(.021)\end{array}$ & $\begin{array}{c}.094 \\
(.021)\end{array}$ & $\begin{array}{c}.092 \\
(.021)\end{array}$ & $\begin{array}{c}.094 \\
(.020)\end{array}$ \\
\hline $0<$ miles $<=0.25$ & $\begin{array}{l}.082 \\
(.024)\end{array}$ & $\begin{array}{l}.054 \\
(.027)\end{array}$ & $\begin{array}{l}.055 \\
(.028)\end{array}$ & $\begin{array}{c}.053 \\
(.027)\end{array}$ & $\begin{array}{l}.086 \\
(.024)\end{array}$ & $\begin{array}{l}.078 \\
(.023)\end{array}$ & $\begin{array}{l}.076 \\
(.023)\end{array}$ & $\begin{array}{c}.077 \\
(.023)\end{array}$ \\
\hline $0.25<$ miles $<=0.5$ & $\begin{array}{c}.031 \\
(.034)\end{array}$ & $\begin{array}{c}.044 \\
(.040)\end{array}$ & $\begin{array}{c}.046 \\
(.040)\end{array}$ & $\begin{array}{c}.042 \\
(.040)\end{array}$ & $\begin{array}{c}.078 \\
(.034)\end{array}$ & $\begin{array}{c}.097 \\
(.034)\end{array}$ & $\begin{array}{c}.096 \\
(.034)\end{array}$ & $\begin{array}{c}.097 \\
(.034)\end{array}$ \\
\hline $0.5<$ miles $<=1$ & $\begin{array}{c}.020 \\
(.037)\end{array}$ & $\begin{array}{c}.003 \\
(.043)\end{array}$ & $\begin{array}{c}.005 \\
(.043)\end{array}$ & $\begin{array}{c}.006 \\
(.043)\end{array}$ & $\begin{array}{l}-.029 \\
(.036)\end{array}$ & $\begin{array}{l}-.034 \\
(.035)\end{array}$ & $\begin{array}{l}-.037 \\
(.035)\end{array}$ & $\begin{array}{l}-.037 \\
(.035)\end{array}$ \\
\hline Proportion of customers black & - & $\begin{array}{c}.549 \\
(.051)\end{array}$ & $\begin{array}{c}.557 \\
(.052)\end{array}$ & $\begin{array}{c}.554 \\
(.051)\end{array}$ & - & $\begin{array}{c}.698 \\
(.042)\end{array}$ & $\begin{array}{c}.695 \\
(.042)\end{array}$ & $\begin{array}{c}.696 \\
(.042)\end{array}$ \\
\hline Position dummies & No & No & Yes & Yes & No & No & Yes & Yes \\
\hline Position dummies*black respondent & No & No & No & Yes & No & No & No & Yes \\
\hline $\mathrm{R}^{2}$ & .194 & .275 & .276 & .284 & .327 & .468 & .470 & .474 \\
\hline$\underline{N}$ & 2,054 & 1,476 & 1,476 & 1,476 & 1,418 & 1,216 & 1,216 & 1,216 \\
\hline
\end{tabular}

Notes: Standard errors are in parentheses. All regressions include a constant term and all of the firm characteristics and indicators of skill needs and job requirements listed in Appendix Table 4A. 
probability that the last workers hired is black declines with distance at a relatively faster rate than for white employers. For the proportion of applicants who are black, we also observe strong negative and significant effects of distance. In addition, none of the interaction terms between the respondent's race and relative distance are significant. However, three of the point estimates are positive and, for the last specification (regression 8), nearly large enough to offset the base distance effect.

While there is no exact corollary to the recent-hires-to-applicants ratios presented in Tables 2

and 4, the parameter estimates in Table 5 do indicate that the ratio of black new hires to applicants declines at a faster rate with distance for black employers than for white employers. This can be seen by computing the distance effects by race (the coefficient on relative distance for white and the sum of the coefficient on distance and the interaction term for blacks) for each outcome and then taking the ratio. For white employers, the probability of a recent black hire declines at a slower rate than the decline in applicants, indicating that the ratio of new hires to applicants increases with distance. For black employers, on the other hand, the probability of a recent black hire decreases at a faster rate than the proportion of applicants who are black, thus indicating that ratios decline with the relative distance from the black community. Hence, using a continuous measure of a firm's proximity to blacks rather than the central-city/suburban dichotomy does not affect the results.

\section{CONCLUSIONS}

Our results indicate several strong patterns. In both the unadjusted DD calculations and the multivariate regressions, we find differences in employment outcomes between black employers in the central city and those in the suburbs that are comparable to, or even larger than, the geographic differences for white firms. On the surface, these results suggest that white suburban firms may be no more discriminatory than white central-city firms, and that much of the mean difference in racial hiring 
and application outcomes among white firms may be attributed to spatial frictions. However, the lower tendency of black suburban employers to hire from their pool of black applicants, relative to black central-city employers, requires further study. Whether suburban employers of either race have legitimate concerns about central-city applicants, or whether both have discriminatory preferences relative to their central-city counterparts, remains unclear. Nonetheless, whatever the factors are that drive the low relative representation of black workers among the applicants to, and employees of, suburban firms, they appear to operate in a similar fashion among both black and white employers. Regardless of geographic differences, race does not appear to be a neutral factor in hiring decisions. For our sample in general and within region, firms with black hiring agents have a higher percentage of their workforce that is black, are more likely to have recently hired a black applicant, and receive a much greater proportion of their applications from black job seekers. Thus, both the race and the location of the employer are clearly important factors in determining firm-level outcomes. Furthermore, the relatively high percentage of black applicants to black suburban firms and the relatively low percentage to white central-city firms suggest that physical distance may matter much less in determining where black workers apply for jobs than do information flows or perceptions of fair treatment.

An important limitation to the current analysis is the inability to detect whether suburban firms in general choose suburban locations to maximize access to a self-selected, relatively high-skilled workforce. To the extent that more able workers migrate to the suburbs and that firms place value on physical proximity to such employees, the existing central-city labor force may not perform well in suburban job markets even with improved physical accessibility (Fernandez 1997). This could be due to the fact that such workers may not meet the demands of suburban employers. Hence, while we are able to show that space determines employment outcomes independently of the geography of discrimination, our controls for the skill needs and qualification demands of employers are not likely to be sufficient to 
decisively rule out the possibility that the spatial effects we observe are driven by the selective migration of workers to suburban neighborhoods. Future research should attempt to evaluate this hypothesis and others concerning self-selection bias in mismatch research. A finer understanding of these issues will provide information important to designing, and choosing among, alternative policy tools. 
APPENDIX TABLE A1

Means and DD Calculations for the Proportion of Noncollege Employees Who Are Black, by MSA

\begin{tabular}{|c|c|c|c|c|c|c|c|c|}
\hline & \multicolumn{2}{|c|}{ All Firms } & \multicolumn{2}{|c|}{ Central City } & \multicolumn{2}{|c|}{ Suburb } & \multicolumn{2}{|c|}{ Difference } \\
\hline \multicolumn{9}{|c|}{ Atlanta } \\
\hline All firms & .303 & $(.012)$ & .387 & $(.020)$ & .249 & $(.013)$ & .138 & $(.023)$ \\
\hline White person in charge of hiring & .279 & $(.012)$ & .340 & $(.020)$ & .243 & $(.014)$ & .097 & $(.024)$ \\
\hline Black person in charge of hiring & .556 & $(.038)$ & .734 & $(.035)$ & .343 & $(.048)$ & .391 & $(.058)$ \\
\hline Difference & -.276 & $(.039)$ & -.394 & $(.056)$ & -.100 & $(.054)$ & -.293 & $(.077)$ \\
\hline \multicolumn{9}{|c|}{ Boston } \\
\hline All firms & .091 & $(.006)$ & .228 & $(.024)$ & .062 & $(.005)$ & .166 & $(.016)$ \\
\hline White person in charge of hiring & .084 & $(.006)$ & .203 & $(.024)$ & .061 & $(.005)$ & .142 & $(.016)$ \\
\hline Black person in charge of hiring & .408 & $(.076)$ & .506 & $(.097)$ & .183 & $(.058)$ & .324 & $(.149)$ \\
\hline Difference & -.323 & $(.045)$ & -.303 & $(.084)$ & -.122 & $(.060)$ & -.182 & $(.092)$ \\
\hline \multicolumn{9}{|c|}{ Los Angeles } \\
\hline All firms & .119 & $(.008)$ & .163 & $(.020)$ & .107 & $(.009)$ & .056 & $(.019)$ \\
\hline White person in charge of hiring & .098 & $(.007)$ & .129 & $(.018)$ & .090 & $(.007)$ & .038 & $(.017)$ \\
\hline Black person in charge of hiring & .368 & $(.045)$ & .442 & $(.061)$ & .335 & $(.060)$ & .107 & $(.095)$ \\
\hline Difference & -.270 & $(.027)$ & -.313 & $(.056)$ & -.245 & $(.031)$ & -.069 & $(.059)$ \\
\hline \multicolumn{9}{|c|}{ Detroit } \\
\hline All firms & .190 & $(.011)$ & .501 & $(.033)$ & .135 & $(.009)$ & .366 & $(.027)$ \\
\hline White person in charge of hiring & .165 & $(.010)$ & .421 & $(.038)$ & .127 & $(.009)$ & .293 & $(.028)$ \\
\hline Black person in charge of hiring & .680 & $(.042)$ & .817 & $(.030)$ & .465 & $(.078)$ & .352 & $(.071)$ \\
\hline Difference & -.515 & $(.046)$ & -.396 & $(.072)$ & -.338 & $(.061)$ & -.059 & $(.088)$ \\
\hline
\end{tabular}

Note: Standard errors are in parentheses. 


\section{APPENDIX TABLE A2}

Means and DD Calculations for the Last Noncollege Employee Hired Is Black, by MSA

\begin{tabular}{|c|c|c|c|c|c|c|c|c|}
\hline & \multicolumn{2}{|c|}{ All Firms } & \multicolumn{2}{|c|}{ Central City } & \multicolumn{2}{|c|}{ Suburb } & \multicolumn{2}{|c|}{ Difference } \\
\hline \multicolumn{9}{|c|}{ Atlanta } \\
\hline All firms & .335 & $(.018)$ & .387 & $(.020)$ & .249 & $(.013)$ & .138 & $(.023)$ \\
\hline White person in charge of hiring & .279 & $(.012)$ & .340 & $(.020)$ & .243 & $(.014)$ & .097 & $(.024)$ \\
\hline Black person in charge of hiring & .556 & $(.038)$ & .734 & $(.035)$ & .343 & $(.048)$ & .390 & $(.058)$ \\
\hline Difference & -.276 & $(.039)$ & -.394 & $(.056)$ & -.100 & $(.054)$ & -.293 & $(.077)$ \\
\hline \multicolumn{9}{|c|}{ Boston } \\
\hline All firms & .091 & $(.011)$ & .228 & $(.024)$ & .062 & $(.005)$ & .166 & $(.016)$ \\
\hline White person in charge of hiring & .084 & $(.006)$ & .203 & $(.024)$ & .061 & $(.005)$ & .142 & $(.016)$ \\
\hline Black person in charge of hiring & .408 & $(.076)$ & .506 & $(.097)$ & .183 & $(.058)$ & .324 & $(.150)$ \\
\hline Difference & -.323 & $(.045)$ & -.303 & $(.084)$ & -.122 & $(.060)$ & -.182 & $(.092)$ \\
\hline \multicolumn{9}{|c|}{ Los Angeles } \\
\hline All firms & .119 & $(.008)$ & .163 & $(.020)$ & .107 & $(.009)$ & .056 & $(.019)$ \\
\hline White person in charge of hiring & .098 & $(.007)$ & .129 & $(.018)$ & .090 & $(.007)$ & .039 & $(.017)$ \\
\hline Black person in charge of hiring & .368 & $(.045)$ & .442 & $(.061)$ & .335 & $(.060)$ & .107 & $(.095)$ \\
\hline Difference & -.271 & $(.027)$ & -.313 & $(.056)$ & -.245 & $(.031)$ & -.069 & $(.059)$ \\
\hline \multicolumn{9}{|c|}{ Detroit } \\
\hline All firms & .190 & $(.011)$ & .501 & $(.033)$ & .135 & $(.009)$ & .366 & $(.027)$ \\
\hline White person in charge of hiring & .165 & $(.010)$ & .421 & $(.038)$ & .127 & $(.009)$ & .293 & $(.028)$ \\
\hline Black person in charge of hiring & .680 & $(.042)$ & .817 & $(.030)$ & .465 & $(.078)$ & .352 & $(.072)$ \\
\hline Difference & -.515 & $(.046)$ & -.396 & $(.073)$ & -.338 & $(.061)$ & -.059 & $(.088)$ \\
\hline
\end{tabular}

Note: Standard errors are in parentheses. 


\section{APPENDIX TABLE A3}

Means and DD Calculations for the Proportion of Applicants Who Are Black, by MSA

\begin{tabular}{|c|c|c|c|c|c|c|c|c|}
\hline & \multicolumn{2}{|c|}{ All Firms } & \multicolumn{2}{|c|}{ Central City } & \multicolumn{2}{|c|}{ Suburb } & \multicolumn{2}{|c|}{ Difference } \\
\hline \multicolumn{9}{|c|}{ Atlanta } \\
\hline All firms & .452 & $(.017)$ & .586 & $(.027)$ & .362 & $(.020)$ & .225 & $(.034)$ \\
\hline White person in charge of hiring & .427 & $(.018)$ & .545 & $(.030)$ & .354 & $(.021)$ & .191 & $(.036)$ \\
\hline Black person in charge of hiring & .697 & $(.056)$ & .850 & $(.064)$ & .478 & $(.085)$ & .372 & $(.105)$ \\
\hline Difference & -.270 & $(.058)$ & -.305 & $(.079)$ & -.124 & $(.083)$ & -.181 & $(.115)$ \\
\hline \multicolumn{9}{|c|}{ Boston } \\
\hline All firms & .171 & $(.011)$ & .351 & $(.036)$ & .134 & $(.011)$ & .217 & $(.029)$ \\
\hline White person in charge of hiring & .166 & $(.012)$ & .338 & $(.038)$ & .135 & $(.011)$ & .203 & $(.030)$ \\
\hline Black person in charge of hiring & .346 & $(.083)$ & .487 & $(.101)$ & .065 & $(.032)$ & .423 & $(.141)$ \\
\hline Difference & -.179 & $(.076)$ & -.149 & $(.123)$ & .070 & $(.112)$ & -.220 & $(.155)$ \\
\hline \multicolumn{9}{|c|}{ Los Angeles } \\
\hline All firms & .224 & $(.015)$ & .227 & $(.017)$ & .223 & $(.029)$ & .004 & $(.035)$ \\
\hline White person in charge of hiring & .197 & $(.014)$ & .200 & $(.031)$ & .196 & $(.016)$ & .004 & $(.034)$ \\
\hline Black person in charge of hiring & .483 & $(.061)$ & .435 & $(.067)$ & .499 & $(.083)$ & -.064 & $(.141)$ \\
\hline Difference & -.286 & $(.048)$ & -.236 & $(.088)$ & -.304 & $(.057)$ & .068 & $(.110)$ \\
\hline \multicolumn{9}{|c|}{ Detroit } \\
\hline All firms & .378 & $(.022)$ & .716 & $(.049)$ & .318 & $(.023)$ & .397 & $(.057)$ \\
\hline White person in charge of hiring & .343 & $(.022)$ & .639 & $(.056)$ & .302 & $(.023)$ & .337 & $(.065)$ \\
\hline Black person in charge of hiring & .864 & $(.060)$ & .947 & $(.089)$ & .760 & $(.064)$ & .187 & $(.120)$ \\
\hline Difference & -.521 & $(.083)$ & -.308 & $(.108)$ & -.457 & $(.120)$ & .149 & $(.167)$ \\
\hline
\end{tabular}

Note: Standard errors are in parentheses. 
APPENDIX TABLE A4

Means of Firm Characteristics by Race of Person in Charge of Hiring and Firm Location

\begin{tabular}{|c|c|c|c|c|c|c|}
\hline \multirow[b]{2}{*}{ Variables } & \multicolumn{3}{|c|}{ Black Respondents } & \multicolumn{3}{|c|}{ White Respondents } \\
\hline & All & $\begin{array}{c}\text { Central } \\
\text { City }\end{array}$ & Suburb & All & $\begin{array}{c}\text { Central } \\
\text { City }\end{array}$ & Suburb \\
\hline $\begin{array}{l}\text { Relative distance to the black } \\
\text { population }^{\text {a }}\end{array}$ & .66 & .58 & .75 & .77 & .64 & .82 \\
\hline Proportion of customers black & .37 & .46 & .28 & .18 & .24 & .16 \\
\hline \multicolumn{7}{|l|}{ Firm characteristics } \\
\hline 1-19 employees & .28 & .31 & .24 & .32 & .29 & .34 \\
\hline 20-99 employees & .26 & .22 & .31 & .34 & .31 & .34 \\
\hline 100-499 employees & .28 & .27 & .29 & .25 & .27 & .24 \\
\hline 500-999 employees & .05 & .04 & .06 & .04 & .04 & .04 \\
\hline $1,000+$ employees & .13 & .16 & .10 & .05 & .09 & .04 \\
\hline Union & .26 & .30 & .21 & .19 & .20 & .18 \\
\hline Mining & .00 & .01 & - & .00 & .00 & .00 \\
\hline Construction & - & - & - & .03 & .02 & .03 \\
\hline Manufacturing & .09 & .06 & .14 & .22 & .14 & .24 \\
\hline $\mathrm{TCU}$ & .06 & .06 & .06 & .05 & .07 & .05 \\
\hline Wholesale trade & .03 & .01 & .04 & .08 & .07 & .08 \\
\hline Retail trade & .21 & .22 & .20 & .17 & .14 & .18 \\
\hline FIRE & .08 & .07 & .09 & .10 & .14 & .09 \\
\hline Services & .45 & .50 & .40 & .31 & .39 & .29 \\
\hline Atlanta & .39 & .47 & .32 & .26 & .44 & .20 \\
\hline Boston & .08 & .10 & .06 & .26 & .19 & .28 \\
\hline Los Angeles & .29 & .14 & .44 & .21 & .21 & .21 \\
\hline Detroit & .24 & .29 & .19 & .27 & .16 & .30 \\
\hline
\end{tabular}

(table continues) 


\begin{tabular}{|c|c|c|c|c|c|c|}
\hline \multirow[b]{2}{*}{ Variables } & \multicolumn{3}{|c|}{ Black Respondents } & \multicolumn{3}{|c|}{ White Respondents } \\
\hline & All & $\begin{array}{c}\text { Central } \\
\text { City }\end{array}$ & Suburb & All & $\begin{array}{l}\text { Central } \\
\text { City }\end{array}$ & Suburb \\
\hline \multicolumn{7}{|l|}{ Daily job tasks } \\
\hline Customer contact & .68 & .75 & .60 & .57 & .60 & .57 \\
\hline Phone conversation & .64 & .67 & .61 & .52 & .58 & .50 \\
\hline Reading & .59 & .66 & .52 & .55 & .57 & .54 \\
\hline Writing & .40 & .44 & .34 & .29 & .29 & .29 \\
\hline Math/computations & .59 & .60 & .58 & .66 & .64 & .67 \\
\hline Computer work & .61 & .58 & .63 & .51 & .56 & .49 \\
\hline \multicolumn{7}{|l|}{$\begin{array}{l}\text { Job qualifications that are either } \\
\text { absolutely necessary or strongly } \\
\text { preferred }\end{array}$} \\
\hline High school diploma & .82 & .84 & .79 & .71 & .75 & .70 \\
\hline Recent work experience & .73 & .68 & .78 & .68 & .74 & .67 \\
\hline Specific experience & .61 & .58 & .65 & .60 & .65 & .59 \\
\hline References & .79 & .74 & .85 & .72 & .74 & .71 \\
\hline Vocational education & .47 & .45 & .49 & .37 & .37 & .36 \\
\hline $\begin{array}{l}\text { Use affirmative action in } \\
\text { recruiting }\end{array}$ & .64 & .62 & .66 & .53 & .54 & .52 \\
\hline Use affirmative action in hiring & .43 & .44 & .43 & .37 & .39 & .37 \\
\hline \multicolumn{7}{|l|}{$\begin{array}{l}\text { Respondent's position within } \\
\text { the firm }\end{array}$} \\
\hline Owner & .14 & .19 & .08 & .15 & .12 & .16 \\
\hline Manager/supervisor & .35 & .27 & .44 & .45 & .49 & .44 \\
\hline Personnel dept. official & .40 & .37 & .42 & .29 & .30 & .29 \\
\hline Other & .11 & .17 & .06 & .11 & .09 & .11 \\
\hline $\mathrm{N}$ & 209 & 115 & 94 & 2,383 & 595 & 1,788 \\
\hline
\end{tabular}

Note: All figures are weighted.

${ }^{a}$ Relative distance is the average distance in miles to black metropolitan residents divided by the average distance to white metropolitan residents. 


\section{References}

Bates, Timothy. 1993. Banking on Black Enterprise: The Potential of Emerging Firms for Revitalizing Urban Economies. Washington, DC: Joint Center for Political and Economic Studies.

_ 1994. "Utilization of Minority Employees in Small Business: A Comparison of Nonminority and Black-Owned Urban Enterprises." Review of Black Political Economy 23 (summer): 113-121.

Becker, Gary. 1971. The Economics of Discrimination. Chicago: University of Chicago Press.

Bendick, Marc, Charles W. Jackson, and Victor A. Reinoso. 1994. "Measuring Employment Discrimination through Controlled Experiments." Review of Black Political Economy 23 (summer): $25-48$.

Bloch, Farrell. 1994. Antidiscrimination Law and Minority Employment: Recruitment Practices and Regulatory Constraints. Chicago: University of Chicago Press.

Ellwood, David T. 1986. "The Spatial Mismatch Hypothesis: Are There Teenage Jobs Missing in the Ghetto?” In The Black Youth Employment Crisis, edited by Richard B. Freeman and Harry J. Holzer. Chicago: University of Chicago Press.

Fernandez, Robert M. 1997. "Spatial Mismatch: Housing, Transportation and Employment in Regional Perspective." In The Urban Crisis: Linking Research to Action, edited by Burton Weisbrod and James Worthy. Evanston, IL: Northwestern University Press.

Frey, William H., and Reynolds Farley. 1996. "Latino, Asian, and Black Segregation in U.S. Metropolitan Areas: Are Multiethnic Metros Different?” Demography 33 (1): 35-50.

Holzer, Harry J. 1996. What Employers Want: Job Prospects for Less-Educated Workers. New York: Russell Sage Foundation.

Holzer, Harry J., and Keith R. Ihlanfeldt. 1996. "Spatial Factors and the Employment of Blacks at the Firm Level." New England Economic Review: Federal Reserve Bank of Boston, May/June: 65-86.

—. Forthcoming. "Customer Discrimination and Employment Outcomes for Minority Workers." Quarterly Journal of Economics.

Holzer, Harry J., Keith R. Ihlanfeldt, and David J. Sjoquist. 1994. "Work, Search, and Travel among White and Black Youth.” Journal of Urban Economics 35: 320-345.

Hughes, Mark, and Julie Sternberg. 1992. The New Metropolitan Reality. Washington, DC: Urban Institute. 
Ihlanfeldt, Keith R. 1992. Job Accessibility and the Employment and School Enrollment of Teenagers. Kalamazoo, MI: W. E. Upjohn Institute for Employment Research.

Ihlanfeldt, Keith R., and David L. Sjoquist. 1990. "Job Accessibility and Racial Differences in Youth Employment Rates.” American Economic Review 80 (1): 267-276.

- 1991. "The Effect of Job Access on Black and White Youth Employment: A Cross-Sectional Analysis." Urban Studies 28 (2): 255-265.

Ihlanfeldt, Keith R., and Madelyn V. Young. 1996. "The Spatial Distribution of Black Employment between the Central City and the Suburbs.” Economic Inquiry 34 (4): 693-707.

Kain, John F. 1968. "Housing Segregation, Negro Employment, and Metropolitan Decentralization." Quarterly Journal of Economics 82 (2): 175-197.

Kasarda, John. 1985. "Urban Change and Minority Opportunities." In The New Urban Reality, edited by Paul E. Peterson. Washington, DC: Brookings Institution.

- 1989. "Urban Industrial Transition and the Underclass." Annals of the American Academy of Political and Social Science 501: 26-47.

Leonard, Jonathan. 1985. "Space, Time and Unemployment: Los Angeles 1980.” Unpublished manuscript, University of California, Berkeley.

- 1987. "The Interaction of Residential Segregation and Employment Discrimination." Journal of Urban Economics 21: 323-346.

Massey, Douglas, and Nancy Denton. 1993. American Apartheid: Segregation and the Making of the Underclass. Cambridge, MA: Harvard University Press.

O'Regan, Katherine M., and John M. Quigley. 1996. "Spatial Effects upon Employment Outcomes: The Case of New Jersey Teenagers." New England Economic Review: Federal Reserve Bank of Boston, May/June: 41-57.

Raphael, Steven. 1998a. "The Spatial Mismatch Hypothesis of Black Youth Joblessness: Evidence from the San Francisco Bay Area." Journal of Urban Economics 43 (1): 79-111.

—. 1998b. "Inter- and Intra-Ethnic Comparisons of the Central City-Suburban Youth Employment Differential: Evidence from the Oakland Metropolitan Area." Industrial and Labor Relations Review 51 (3): 505-524.

Stoll, Michael A. Forthcoming. "Spatial Mismatch, Discrimination, and Male Youth Employment in the Washington, DC Area: Implications for Residential Mobility Policies." Journal of Policy Analysis and Management 18 (1). 
Taylor, Brian D., and Paul M. Ong. 1995. "Spatial Mismatch or Automobile Mismatch? An Examination of Race, Residence, and Commuting in US Metropolitan Areas." Urban Studies 32 (9): $1453-1473$.

Turner, Susan C. 1997. "Barriers to a Better Break: Employer Discrimination and Spatial Mismatch in Metropolitan Detroit." Journal of Urban Affairs 19 (2): 123-141.

Yinger, John. 1995. Closed Doors, Opportunities Lost: The Continuing Costs of Housing Discrimination. New York: Russell Sage Foundation. 